\title{
スタッドを有する鋼コンクリート界面における引張 応力依存型の付着性状に関する研究
}

\begin{abstract}
外山 征 $^{* 1} \cdot$ 大下 英吉*2
概 要 実構造物における鋼コンクリート合成・複合構造, CFT 柱梁部等の変形挙動を詳細に評価するには, 複 合忘力が作用した状態における付着性状を評価しなければならない。著者等 1) は, 既にスタッド軸方向に圧縮力を 作用させた場合の鋼コンクリート界面における付着性状に関する研究を行い, 付着性状がスタッド軸方向の圧縮力に 依存することを報告しているが, スタッド軸方向に引張力が作用する場合の定量的評価にまでは至っていない。本研 究では, スタッド軸方向に対して引張力の側圧を載荷した多軸応力状態下における付着性状の定性的かつ定量的評価 を実施した。その結果, 引張力の側圧は付着性状に大きな影響を及ぼすとともに, 破壊性状にも大きな影響を及ぼす ことが明らかとなった。

キーワード : 合成構造, スタッド, 付着性状, 引張応力依存型
\end{abstract}

\section{1. はじめに}

近年，鋼コンクリート間の付着性状に関する研究が見 直されてきている。1995 年 1 月, 阪神一帯を襲った兵庫 県南部地震により, 大規模な被害が生じた。鉄筋コンク リート造や鉄骨造のうち, 崩壊した損傷部位として柱梁 接合部の被害が多く報告されている ${ }^{2)}$ 。その損傷事例と して柱梁接合部には大きなせん断ひび割れの発生やかぶ りコンクリートの剥落等が挙げられており，このことか ら柱梁接合部界面においては多大なせん断荷重, 梁に対 しては多大な曲げが作用しているものと予想される。一 方, 比較的被害の少なかった構造としてコンクリート充 填鋼管柱(CFT 造)などが挙げられ, 耐震性の向上, 工期 短縮, 高い施工性の利点等から今後も多用されていくも のと思われる。

鋼コンクリート合成・複合構造, CFT 柱梁部等におい て, ずれ止めとしての頭付きスタッドは重要な接合構造 として多く用いられている。ずれ止めは, 鋼桁の上フラ ンジと床版との接触面に働くせん断力を相互に伝達し, 両者の間のす心゙りを止めることを主目的とするとともに， 床版の浮き上がりを防止するものである。頭付きスタッ ドがずれ止めとしての用途で鋼コンクリートの合成構造 物に多く用いられている理由として, 実施工において容 易に鋼材に接合可能な優れた施工性を持つこと，鋼とコ
ンクリートの付着を十分に取り一体化させることにより 高い剛性を期待できるものであることが挙げられる。一 方，実構造物において，鋼とコンクリート界面に存在す るスタッドには，柱および梁に常時荷重として作用する 活荷重および衝撃荷重等により発生する曲げモーメント によって圧縮および引張の直応力が作用した状態でせん 断荷重が載荷されるという複合応力状態であり，スタッ ド軸方向の応力性状によりせん断挙動或いは破壊性状は 全く異なることが想定される。また，昨今の鋼コンクリ 一ト合成桁橋においては, 軽量化, 施工の合理化および コスト削減の目的により, 上床版の幅員の長大化および 波形鋼板ウェブの使用が盛んに実施されている。例えば, 第二東名高速道路においては, 片側三車線, 有効幅員十 数 $\mathrm{m}$ であり，これを波形鋼板ウェブを有する $\mathrm{PC}$ 箱桁 1 本で支持することによりウェブ閒隔 $10 \mathrm{~m}$ の橋が計画さ れている。このような構造形式の場合, 上床版の死荷重 および活荷重により, 横方向曲げモーメントに起因し複 合部である鋼桁上フランジ面に配置されたスタッドには, スタッド軸方向に引張力或いは圧縮力が働いた状態にお いてせん断力が作用することになる。さらに，従来の I 桁に比べて横方向剛性が大きいため，接合部においてス タッド軸方向への引張力或いは圧縮力は大きいものとな り,上述した応力性状は尚更, 重要なものとなってくる。 このような観点から, 著者等 ${ }^{1)}$ は一面あるいは二面せ

\footnotetext{
*1 中央大学大学院 理工学研究科土木工学専攻 (正会員) † 112-8551 東京都文京区春日 1-13-27

*2 中央大学助教授 理工学部土木工学科 (正会員) $\bar{\top} 112-8551$ 東京都文京区春日 1-13-27
} 
ん断実験により捉えられたスタッドの付着性状はこのよ うな複合応力状態下にある構造物に対して適用が困難で あり，スタッド軸方向の応力性状に依存した付着性状を 詳細に解明しなければならないことを指摘するとともに， スタッド軸方向に圧縮力が作用された状態における付着 性状に関する定量的評価を実施し, 付着性状に及ぼす側 圧の影響は非常に大きいことが明らかになった。そして， より詳細な評価を行うためにはスタッド軸方向に引張力 が作用された状態下における付着性状を詳細に評価しな ければならないことも指摘した。

そこで本研究では, 複合応力状態下におけるスタッド 付き $\mathrm{H}$ 型鋼とコンクリート界面の付着性状を, スタッド 高およびスタッド軸方向への応力性状によらず統一的に

\begin{tabular}{|c|c|c|c|c|}
\hline \multicolumn{5}{|c|}{ 表一 1} \\
\hline $\begin{array}{c}\text { 粗骨材 } \\
\text { の最大 } \\
\text { 寸法 } \\
(\mathrm{mm})\end{array}$ & $\begin{array}{c}\text { スラン } \\
\text { プ值 } \\
(\mathrm{cm})\end{array}$ & $\begin{array}{c}\text { 空気量 } \\
(\%)\end{array}$ & $\begin{array}{c}\text { 水セメ } \\
\text { ント比 } \\
(\%)\end{array}$ & $\begin{array}{c}\text { 細骨材 } \\
\text { 率 } \\
(\%)\end{array}$ \\
\hline 20 & 12 & 4.5 & 55.5 & 45.5 \\
\hline \multicolumn{5}{|c|}{ 単位量 $\left(\mathrm{kg} / \mathrm{m}^{3}\right)$} \\
\hline $\begin{array}{l}\text { 水 } \\
\mathrm{W}\end{array}$ & $\begin{array}{c}\text { セメント } \\
\mathrm{C}\end{array}$ & $\begin{array}{c}\text { 細骨材 } \\
\text { S }\end{array}$ & $\begin{array}{c}\text { 粗骨材 } \\
\text { G }\end{array}$ & 混和材 \\
\hline 159 & 257 & 840 & 1030 & 2.87 \\
\hline
\end{tabular}

\begin{tabular}{c|c|c}
\multicolumn{3}{c}{ 表 -2 スタッドの規格 } \\
\hline \multicolumn{3}{|c}{ 機械的性質 } \\
\hline \hline $\begin{array}{c}\text { 降伏点 } \\
\left(\mathrm{N} / \mathrm{mm}^{2}\right)\end{array}$ & $\begin{array}{c}\text { 引張強さ } \\
\left(\mathrm{N} / \mathrm{mm}^{2}\right)\end{array}$ & $\begin{array}{c}\text { 伸び } \\
\left(\begin{array}{c}\%\end{array}\right)\end{array}$ \\
\hline 235 以上 & $400 \sim 550$ & 20 以上 \\
\hline
\end{tabular}

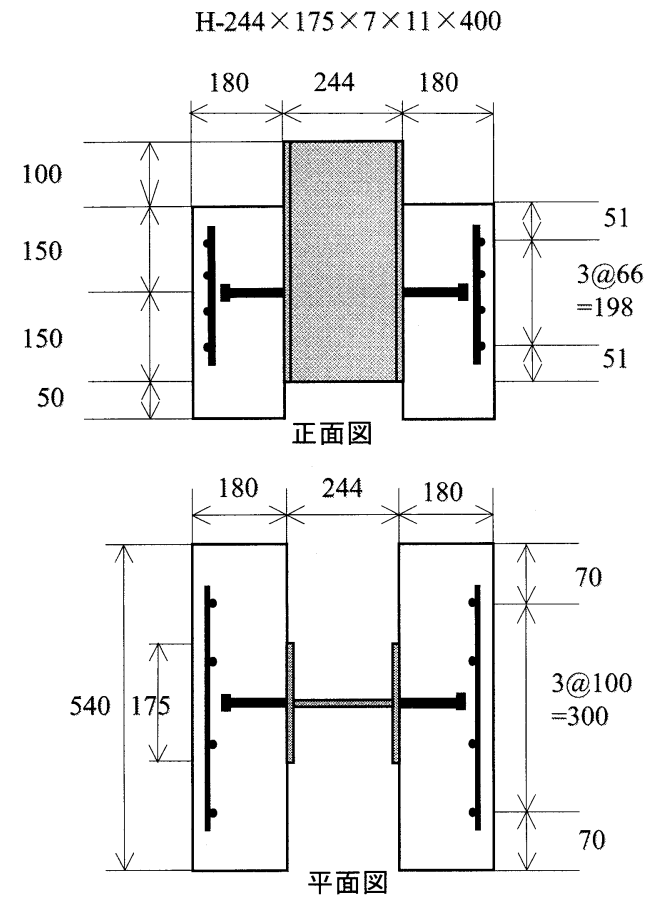

図-1 供試体の寸法 （単位: $\mathrm{mm}$ )
評価可能なモデルの構築を目的として, 従来の押し抜き 試験を改良しコンクリート供試体 ${ }^{3)}$ にスタッド軸方向に 一定の引張力を保持した状態でせん断力を作用させると いう側圧制御式押し抜き試験を行った。

\section{2. 実験概要}

\section{1 実験供試体}

本研究では，鋼コンクリート界面の付着性状に及ぼす スタッド軸方向の引張力に着目するため，スタッド間隔 によるせん断抵抗の影響を考慮しスタッド本数は 1 本と した。コンクリートの配合および改良型押し抜き供試体 の形状寸法は，表一 1 および図一 1 に示す通りである。 なお，鋼コンクリート界面の付着をなくすため表面に凹 凸がなく均一な $\mathrm{H}$ 型鋼を使用するとともにアセトンによ り表面を洗浄した。スタッドに関しては, 径 $\mathrm{d}=16(\mathrm{~mm})$, 高さ $\mathrm{H}=80,100$ および $120(\mathrm{~mm})$ の 3 種類である。な お，スタッドの規格はJIS B 1198 に準じており，機械的 性質は表－ 2 に示す通りである。コンクリートスラブは, 既往の研究 ${ }^{1)}$ との比較のため設計基準強度 $29.4 \mathrm{~N} / \mathrm{mm}^{2}$ と し，スタッド軸方向の引張力によるコンクリートへのひ

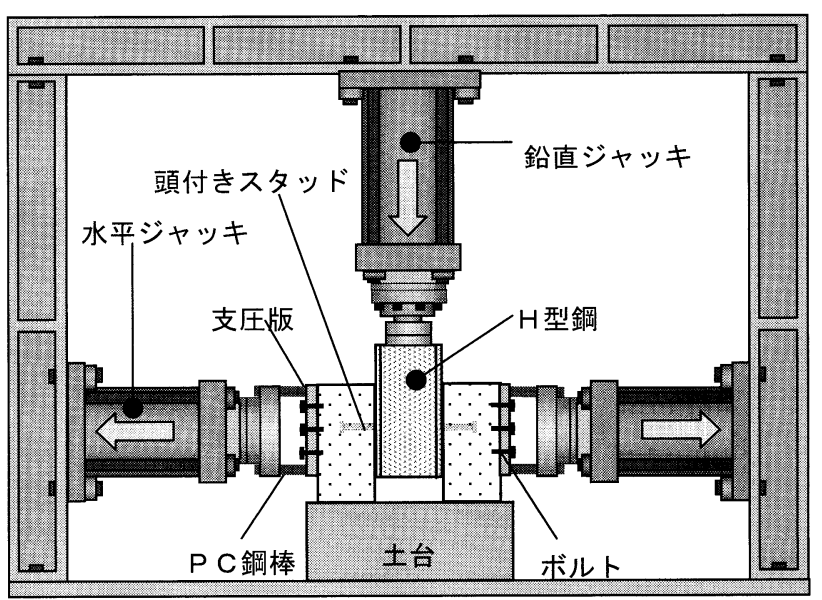

図-2 引張型側圧制御式押し抜き試験法

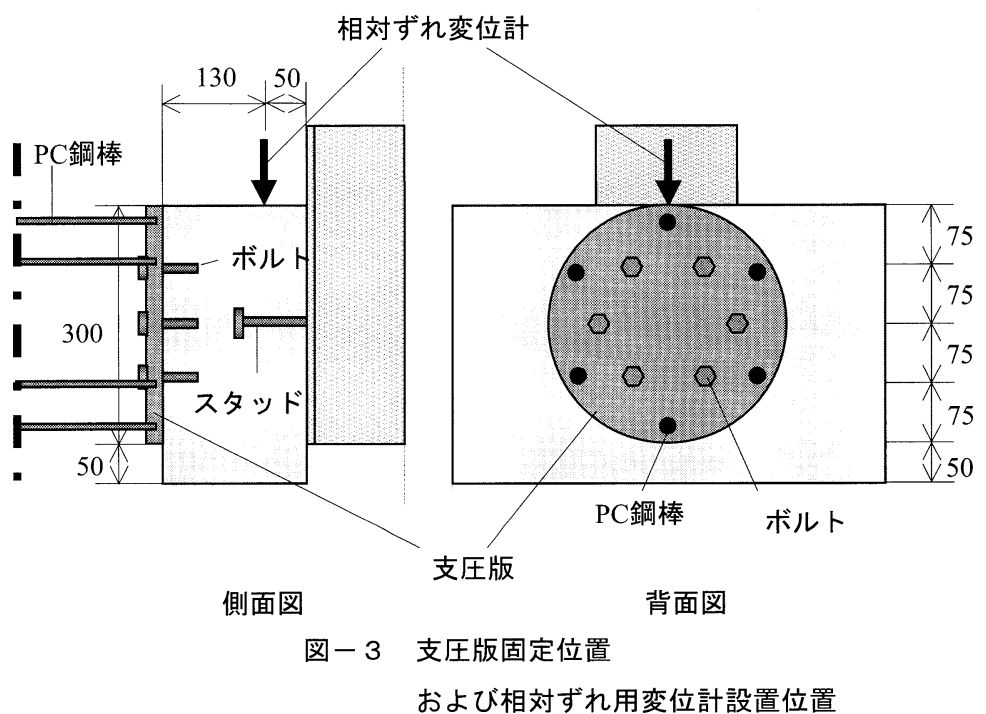




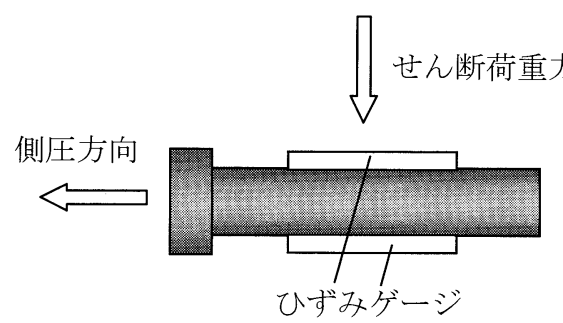

図－4 スタッドへのひずみゲージ貼付位置

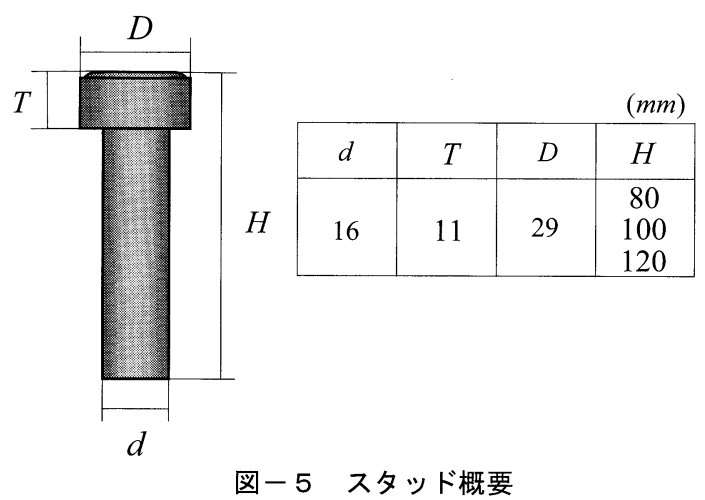

表一3 供試体一覧

\begin{tabular}{|c|c|c|c|c|c|c|}
\hline $\begin{array}{c}\text { 供試体 } \\
\text { 名称 }\end{array}$ & $\begin{array}{c}\text { ス } \\
\text { タ } \\
\text { ツ } \\
\text { ド } \\
\text { 高 } \\
\mathrm{H} \\
\mathrm{mm}\end{array}$ & $\begin{array}{l}\text { 側圧 } \\
\text { 比 } \\
L P \\
\%\end{array}$ & $\begin{array}{c}\text { 圧縮 } \\
\text { 強度 } \\
f_{c}{ }^{\prime} \\
\mathrm{N} / \mathrm{mm}^{2}\end{array}$ & $\begin{array}{c}\text { 引張 } \\
\text { 強度 } \\
f_{t} \\
\mathrm{~N} / \mathrm{mm}^{2}\end{array}$ & $\begin{array}{c}\text { 弾性 } \\
\text { 係数 } \\
E_{c} \\
\mathrm{kN} / \mathrm{mm}^{2}\end{array}$ & $\begin{array}{c}\text { 側圧 } \\
\mathrm{N} / \mathrm{mm}^{2}\end{array}$ \\
\hline H80-0 & 80 & 0 & 22.9 & 2.55 & 23.4 & 0 \\
\hline $\mathrm{H} 100-0$ & 100 & 0 & 22.9 & 2.65 & 26.0 & 0 \\
\hline $\mathrm{H} 120-0$ & 120 & 0 & 26.8 & 2.65 & 26.0 & 0 \\
\hline H80-T20 & 80 & 20 & 23.7 & 2.97 & 24.3 & 0.59 \\
\hline $\mathrm{H} 100-\mathrm{T} 20$ & 100 & 20 & 30.7 & 2.87 & 24.2 & 0.57 \\
\hline H120-T20 & 120 & 20 & 27.8 & 2.74 & 25.5 & 0.55 \\
\hline H80-T30 & 80 & 30 & 27.8 & 2.74 & 25.5 & 0.82 \\
\hline H100-T30 & 100 & 30 & 29.2 & 2.66 & 26.3 & 0.80 \\
\hline H120-T30 & 120 & 30 & 29.2 & 2.66 & 26.3 & 0.80 \\
\hline
\end{tabular}

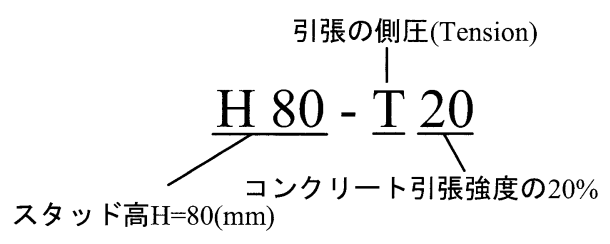

図-6 供試体の名称

び割れ防止のため図ー 1 に示すようにスタッド頭部近傍 にD10の異形鉄筋を格子状に配置した。コンクリートの 打設方向はせん断荷重載荷設置状態の下方から行った。 ブリーディングによる肌離れが生じ，せん断荷重がこの 肌離れを詰める方向に作用する場合にはせん断耐力にか
なりの悪影響があるものと考えられる。なお，従来最も 多用される使用法としての鋼コンクリート桁におけるず れ止めである頭付きスタッドは，正立した状態でスタッ ド頭部の方向から打設されるものであるが，本実験の打 設方向はブリーディングによる肌離れの影響を完全に排 除できることから鋼コンクリート界面のせん断耐力を考 察するには望ましいものと思われる。

\section{2 実験方法}

鋼コンクリート界面におけるせん断力の載荷は, 三軸 試験機の水平ジャッキによってスタッド軸方向に対し所 定の引張力が保持された後で鉛直ジャッキにより上部か ら行い, せん断載荷速度は $0.5 \mathrm{~mm} / \mathrm{min}$ とした。スタッド 軸方向の引張力の載荷方法は, 図一2 に示寸ように支圧 版と三軸試験機の水平ジャッキを PC 鋼棒により固定し 載荷した。

実構造物における応力性状は，曲げの作用によりスタ ッド軸方向への応力およびせん断応力が同時に増加する ものと思われる。しかしながら, 本研究では側圧を一定 に保持した状態でせん断応力を作用させたわけであるが， これは, スタッド軸方向の引張力が付着性状に及ぼす影 響を定量的に把握するためと終局状態に至るまでの応力 経路への側圧の依存性を定性的かつ定量的に評価するた めである。

次に，図ー3に示すように，支圧版をスタッドを中心 とした円上にボルトを用いて供試体と固定し，引張力に よって発生するコンクリートの応力分布がスタッドに対 して均一となるようにした。また，側圧としての引張力 による土台と供試体の摩擦効果を低減させるため, 土台 にオイルを塗付した。コンクリートと $\mathrm{H}$ 型鋼の相対ずれ の測定は，同図に示すようにフランジを中心としたコン クリート上部の左右対称の位置に設置した変位計の平均 值として測定した。なお，本実験における相対ずれは， スタッド頭部がコンクリート中に固定されていると仮定 し，せん断荷重により下方へ移動するスタッド基部位置 とコンクリート中に固定されているスタッド頭部位置と のずれ量と定義する。さらに，鋼コンクリートの付着性 状をより詳細に解明するため，図ー4に示すようにス夕 ッド軸方向の伸縮によるひずみの測定のためのひずみゲ ージを上部と下部に貼り付けた。ひずみゲージ添付位置 はスタッド変形の代表的な值としてスタッドの中央とし た。

\section{3 実験パラメータ}

実験パラメータは, 表ー 3 に示すようにスタッド高 $\mathrm{H}$ および側圧比 $L P$ （Lateral Pressure）であり，各々の実験 パラメータの載荷試験をそれぞれ 1 回行った。スタッド 径は笠井ら ${ }^{1)}$ の行った実験との比較のため $\mathrm{d}=16(\mathrm{~mm})$, ス タッド高は JIS 規格に基づき $\mathrm{H}=80,100,120(\mathrm{~mm})$ とし， 図ー5にスタッド概要を示す。側圧比に関しては, コン クリートの引張強度の $20 \%$ おおび $30 \%$ とた。ここで, 
本研究における側圧は, 図一 2 に示す水平ジャッキによ りコンクリートに載荷された引張力を鋼コンクリート接 地面積で除したものと定義する。また, 本研究で設定し た側圧比であるが，例えば CFT 造における CFT 柱・梁 接合部には梁に集中荷重が作用することによる曲げモー メントにより, その接合部引張縁の鉄筋ひずみが最大で

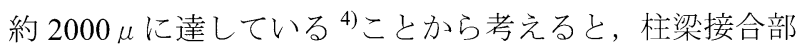
のアンカー材としての頭付きスタッドにも軸方向に対し 非常に大きな引張力が作用しているものと思われる。側 圧比の大きさは, 終局状態において最大で約 $60 \%$ にまで 達するものであり, 接合部におけるスタッドには場所ご とに異なる引張力が作用していることから考えると実構 造物では $0 \%$ から $60 \%$ の側圧比が作用しているものと予 想され, 本研究ではその中間的な值として側圧比を $20 \%$, $30 \%$ とした。

また, コンクリートの圧縮強度, 引張強度および弾性 係数を側圧無しの実験結果とあわせて同表に示し，供試 体の名称説明を図ー6に示す。なお，長期間にわたる実 験であったことからコンクリート練混ぜ時の温度が各供 試体で差異が生じ, 圧縮強度に若干のばらつきが生じた ものと思われる。しかしながら後述するように, コンク リートの破壊に関しては引張強度が重要であり, 各供試 体における引張強度に大きなばらつきがみられないこと から圧縮強度のばらつきが実験結果に及ぼす影響は少な いものと思われる。

\section{3. スタッド引き抜き実験と本研究との比較}

本章では，大谷等 ${ }^{5)}$ の行ったせん断・引張の組合せ荷 重を受けるスタッドについての実験と本研究の実験結果 との比較を行うことにする。

図ー7に大谷等の行った実験のせん断耐力および引張 耐力の耐荷力相関曲線 $(T / T u)^{5 / 3}+(S / S u)^{5 / 3}=1$ を示す。図中

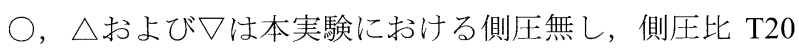

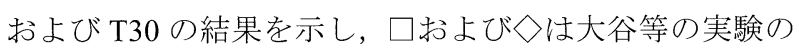
一定引張力におけるせん断載荷および引張 ・ せん断の比 例載荷を示している。なお, コンクリート強度の異なる 実験值を同時に評価するため, 耐荷力は引張力のみを作 用させた場合の耐荷力 $T u$ および本実験における側圧無 し時のせん断耐荷力 $S u$ で除することにより無次元化し ている。また, $T u$ および Suの算出式は以下に示すとお りである。

$$
\begin{aligned}
& T u=1.06 \sqrt{20} \pi d_{e}\left(l_{e}+D\right) \sqrt{f_{c}^{\prime}} \\
& S u=3.34 A_{s} f_{c}^{.0 .3} E_{c}^{0.44}
\end{aligned}
$$

ここで,

$$
l_{e}: \text { スタッド軸部の長さ }(\mathrm{mm})
$$$$
D \text { : スタッド頭部直径 }(\mathrm{mm})
$$

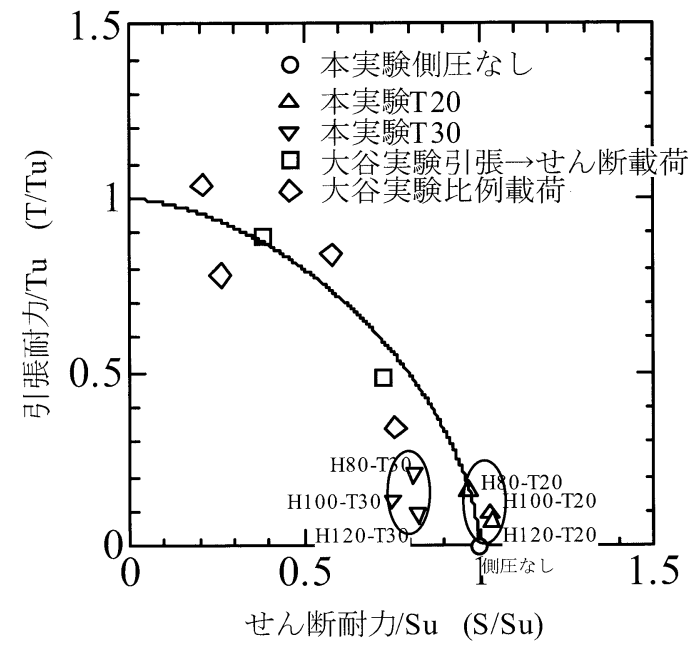

図-7 破壊荷重と耐荷力相関曲線

$$
\begin{aligned}
& A_{s}: \text { スタッド軸部断面積 }\left(\mathrm{mm}^{2}\right) \\
& f_{c}^{\prime}: \text { コンクリートの圧縮強度 }\left(\mathrm{N} / \mathrm{mm}^{2}\right) \\
& E_{c}: \text { コンクリートの弾性係数 }\left(\mathrm{N} / \mathrm{mm}^{2}\right)
\end{aligned}
$$

とする。

同図より本実験供試体は耐荷力相関曲線のなかでも低 引張領域に位置しており, 本実験の側圧比 $20 \%$ の耐荷力 に関しては多少のばらつきはあるもののほぼ耐荷力相関 曲線上に位置している。一方, 本実験の側圧比 $30 \%$ に関 しては, 耐荷力相関曲線とは異なる結果を示しており耐 荷力相関曲線の適用性は認められない。すなわち, 大谷 等の実験では供試体の破壊形態がコンクリート破壊とス タッド破断の 2 種類であり, それらを同一の耐荷力相関 曲線により評価するという問題が挙げられる。なお, 引 張耐力/ Tuの值は, 側压比の大きさ, スタッド高および コンクリート圧縮強度に依存するものであり, 各スタッ ド高とも側圧比 $30 \%$ $20 \%$ に比べ大きな值となっている が，圧縮強度のばらつきが引張耐力/ Tu の值に及ぼす結 果として, 各スタッド高による側圧比の影響が小さくな ったと思われる。

本研究では, 側圧として引張力を保持した状態でのせ ん断力載荷によりスタッド頭部に接するコンクリートに ひび割れが発生することに伴い, スタッドの高さ径比の 差異による供試体の破壊性状が, スタッドと $\mathrm{H}$ 型鋼の溶 接部が破断した H100-T30 を除き同様のコンクリート破 壊となったと考えられ，詳細については次章で述べるこ ととする。さらに, 終局耐力のみの評価では上述の異な る破壊性状を詳細に評価することが困難であるため耐荷 力に至るまでの変形性状および応力性状を詳細に評価す る必要があると思われる。

\section{4. 側圧依存型付着性状}

本章では, 側圧比およびスタッド高をパラメータとし た側圧制御式押し抜き試験における実験結果の比較検討 


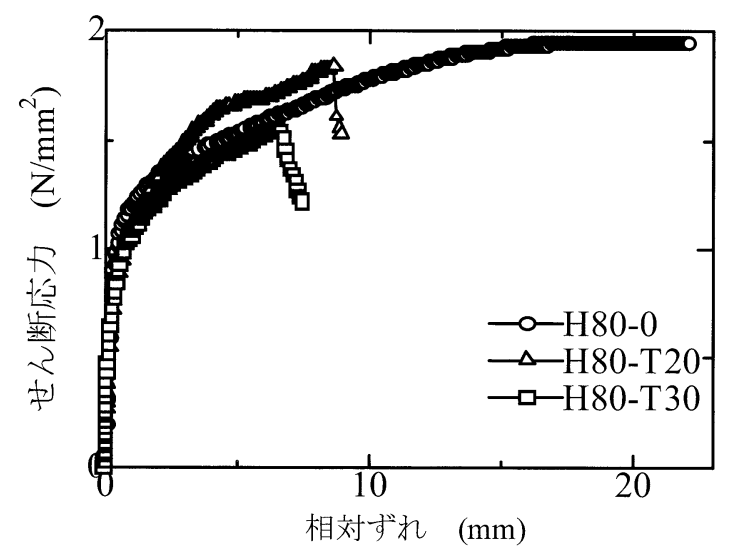

(a) スタッド高 $\mathrm{H}=80 \mathrm{~mm}$

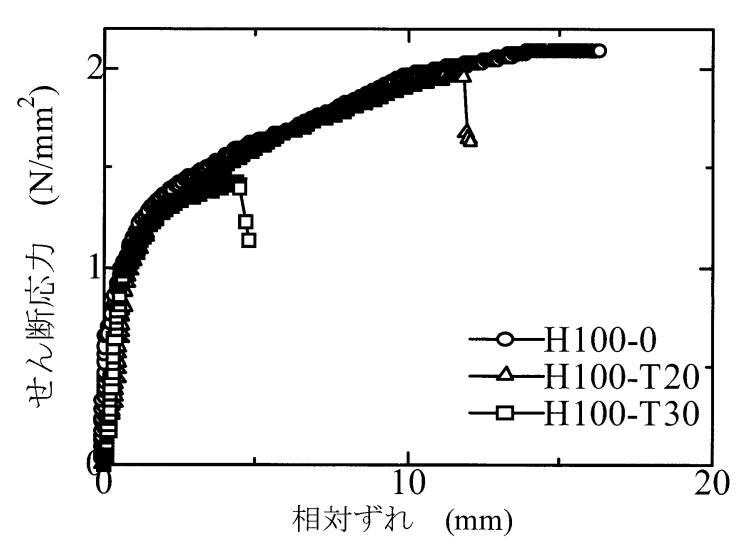

(b) スタッド高 $H=100 \mathrm{~mm}$

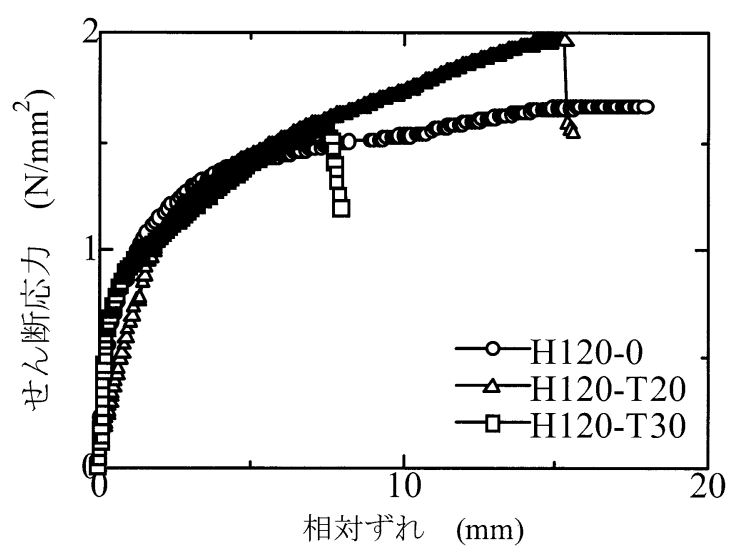

(c) スタッド高 $\mathrm{H}=120 \mathrm{~mm}$

図ー8 側圧有無によるせん断応カー相対ずれ関係

を行い, 鋼とコンクリートの側圧依存型の付着性状につ いて考察する。

付着性状を論じるに際し, スタッドに作用するせん断 力或いは引張力を用いるのではなく，それらを鋼コンク リートの接地面積で除した応力を用いることとし，これ をせん断応力とする。実構造物においては，鋼コンクリ 一ト界面に存在するスタッドの軸方向に作用する応力性 状は, 引張力が作用する箇所もあれば圧縮力が作用する 箇所もあるというように場所によって異なり, それらを 統一的に評価するには, 鋼コンクリートの接地面積を導
表-4 供試体破壊荷重および破壊形式

\begin{tabular}{|c|c|c|c|}
\hline 供試体 & 最大荷重 $(\mathrm{kN})$ & 破壞形式 & $f_{c}^{\prime}\left(\mathrm{N} / \mathrm{mm}^{2}\right)$ \\
\hline H80-0 & 205 & $\begin{array}{c}\text { コンクリート } \\
\text { 破壊 }\end{array}$ & 22.9 \\
\hline H100-0 & 219 & $\begin{array}{c}\text { コンクリート } \\
\text { 破壞 }\end{array}$ & 26.8 \\
\hline H120-0 & 174 & 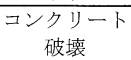 & 26.8 \\
\hline H80-T20 & 193 & $\begin{array}{c}\text { コンクリート } \\
\text { 破壞 }\end{array}$ & 23.7 \\
\hline H100-T20 & 206 & $\begin{array}{c}\text { コンクリート } \\
\text { 破壊 }\end{array}$ & 30.7 \\
\hline H120-T20 & 207 & $\begin{array}{c}\text { コンクリート } \\
\text { 破壊 }\end{array}$ & 27.8 \\
\hline H80-T30 & 162 & $\begin{array}{c}\text { コンクリート } \\
\text { 破壊 }\end{array}$ & 27.8 \\
\hline H100-T30 & 150 & 溶接部破断 & 29.2 \\
\hline H120-T30 & 165 & $\begin{array}{c}\text { コンクリート } \\
\text { 破壊 }\end{array}$ & 29.2 \\
\hline
\end{tabular}

入した応力に基づくことが必要である。また，著者等の 既往の研究 ${ }^{1)}$ との比較を行うためにも, せん断応力およ び側圧により付着性状を論じる必要があるわけである。

\section{1 側圧の有無によるせん断挙動}

はじめに, 鋼とコンクリートの付着性状に及ぼす側圧 の影響を考察する上で, 側圧の有無によるせん断応力一 相対ずれにおける関係の比較を行う。側圧としての引張 力は荷重制御により一定の荷重を保ち，「側圧無し」およ び「側圧有り」ともに土台と供試体の摩擦を低減させる ため土台にはオイルを塗付した状態でせん断力載荷を行 った。

図ー8は，側圧の有無によるせん断応力と相対ずれの 関係を表している。同図（a)，(b) および（c）は，それ ぞれスタッド高 $80 \mathrm{~mm}, 100 \mathrm{~mm}$ および $120 \mathrm{~mm}$ に対する

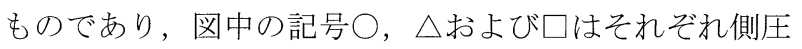
無し，側圧比 $20 \%$ よび側圧比 $30 \%$ を表している。

まず，側圧有無による実験方法の違いを検討する。側 圧無しの場合，せん断荷重により鋼コンクリート界面に 開きを生じさせる曲げが発生する。側圧有りの場合，コ ンクリートには一定の引張力が持続的に作用しており, コンクリートの変形挙動は側圧無しの場合と同様な曲げ による開きが発生していることが確認された。このよう に鋼コンクリート界面における変形性状が側圧有無によ らず同様なものであることから，鋼コンクリート界面に おける変形性状および応力性状を比較し得るものと考え られ,より詳細な評価を以下に行う。

側圧無しおよび側圧有りのいずれの供試体においても， せん断応力は緩やかに同じような経路をたどり増加した。 その後, 側圧有りの引張力として側圧を載荷した供試体 についてはせん断応力が最大值に達した後急激に低下す るというような傾向が確認された。一方, 側圧無しの供 試体については急激にせん断応力が低下するというよう な挙動はみられなかった。相対ずれに関しては, その最 大值は側圧有りの供試体に比べ大きな值となる。

次に, 表一 4 に各供試体における破壊荷重, 破壊形式 およびコンクリート圧縮強度を示す。側圧として引張力 が作用することによってスタッド頭部にひび割れが発生 


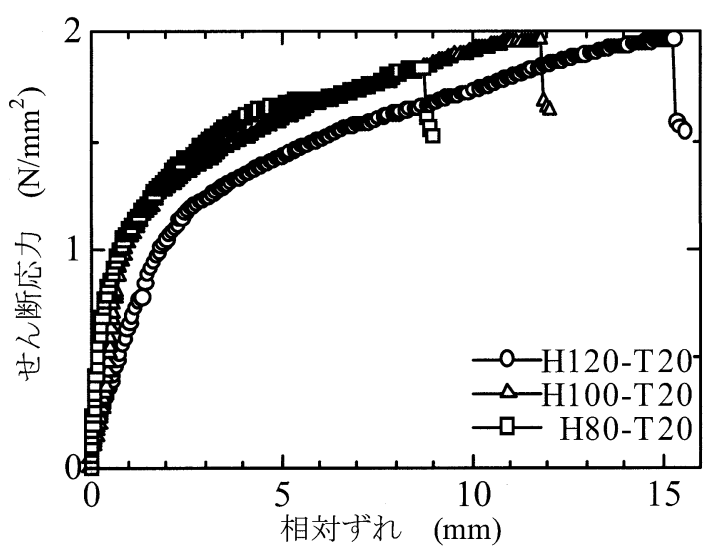

(a) 側圧比 $=20 \%$

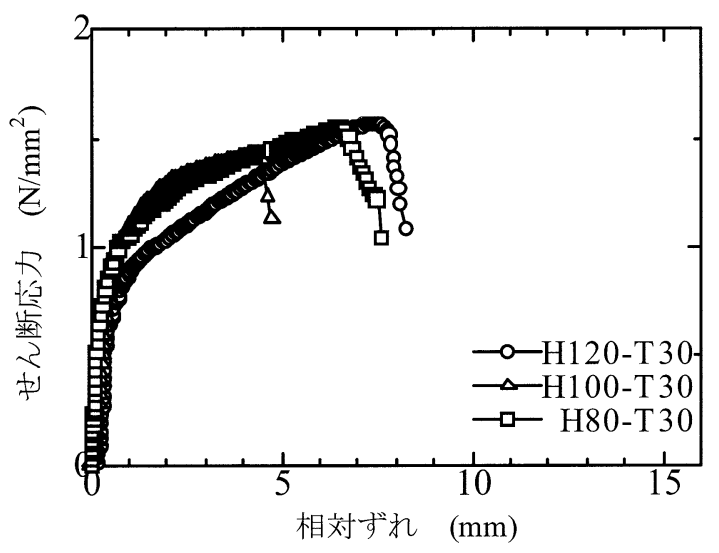

(b) 側圧比 $=30 \%$

図ー9 せん断応カー相対ずれの関係

（側圧比一定）

し, さらに鉛直方向のせん断荷重により, ひび割れが進 展することによるコーン状の引き抜きが起こることから 考えると, スタッド高と径の比 $H / d$ によらずスタッド近 傍のコンクリートの割裂抵抗により各供試体の耐力が決 定される傾向にあると思われる。

以上から, 鋼コンクリート界面における付着性状には, 側圧の有無, 側圧比の大きさおよびスタッド高の影響が あると思われる。このことから，より詳細なスタッド高 および側圧比をパラメータとした引張力として側圧が作 用した状態下における鋼コンクリート界面の付着性状の 評価を行うこととする。

\section{2 せん断応カー相対ずれ関係}

(1) スタッド高に関する影響

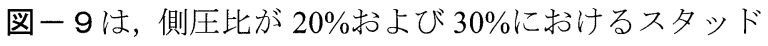
高をパラメータとしたせん断応力と相対ずれの関係を表 している。同図（a）および（b）はそれぞれ側圧比 $20 \%$

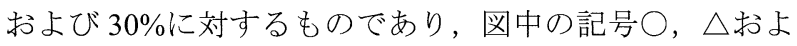
びロは，それぞれ供試体スタッド高 H80, H100 および H120を表している。

まず，いずれの供試体についても同様な初期剛性でせ ん断応力が上昇する傾向が見られた。その後，同図（a） に示す側圧比が $20 \%$ の場合, スタッド高が高くなるにつ れて相対ずれの最大值が大きくなるという傾向を示し,
せん断応力の最大值もわずかではあるが大きくなる傾向 が見られた。スタッド高の高低によるせん断応力増加経 路の差異はみられず，ほぼ同じような経路を辿り最大值 まで上昇した。また，同図（b）に示す側圧比が $30 \%$ の 場合には，スタッド高が $100 \mathrm{~mm}$ である供試体 H100-T30 を除く供試体では, 側圧比が $20 \%$ と同じ傾向を示してい る。このようなスタッド高による相対ずれ, せん断応力 の最大值の増加は, 破壊性状がコーン型の引き抜きに近 い性状を示すという目視観察によることから考えると， スタッド高が高くなることによりコンクリートとスタッ ドの付着面積が増加することによるものであると考えら れる。また，実構造物において常時荷重作用時などの初 期剛性では各スタッド高とも同様の傾向となると予想さ れるが，構造物の終局耐力を考慮する際にはスタッド高 および側圧比の影響は大きいものと思われる。本研究で は，側圧の影響によりスタッド頭部からコーン状にひび 割れが発生し, せん断力の増加に伴いひび割れが進展し, 供試体の破壊形態がコンクリート破壊になったものと考 えられ，H100-T30に関しては，供試体の破壊形式がスタ ッド基部の溶接部での破断であることから, 他の供試体 との直接的な比較は困難であった。

なお，せん断応力の初期剛性が側圧比 $20 \%$ おび $30 \%$ ともにスタッド高が高いほどわずかではあるが初期剛性 が緩やかなものとなっている。また，供試体 H120-T20 に関して，せん断応力の初期剛性が他と比べ緩やかなも のとなっている。このことは，同じ相対ずれに対してス タッド高が高いほど曲げ性状が小さくなるものと考えら れる。したがって，スタッド高に伴う曲げ性状が影響を 及ぼす結果として，供試体 H120-T20 の初期剛性が小さ くなるものと考えられる。

(2) 側圧に関する影響

ここでは図ー8を用いて, せん断応力一相対ずれ関係 に及ぼす側圧比の影響について考察を行う。

まず，いずれの供試体についても，せん断応力は緩や かに増加し, 側圧比 $20 \%$ おび 30\%の供試体に関しては せん断応力の最大值に達した後急激に低下寸るというよ うな非常に脆性的な挙動を示している。このような脆性 的挙動は, せん断応力にスタッドの変形性状が大きく関 与するものであり, その詳細については 4.3 節にて論じ ることとする。

次に, スタッド高 $80 \mathrm{~mm}$ におけるせん断応力の最大值 は，T20，T30においてそれぞれ 1.84，1.55N/ $\mathrm{mm}^{2}$ ，スタ ッド高 $100 \mathrm{~mm}$ ではそれぞれ $1.96,1.43 \mathrm{~N} / \mathrm{mm}^{2}$, スタッド 高 $120 \mathrm{~mm}$ ではそれぞれ $1.97,1.57 \mathrm{~N} / \mathrm{mm}^{2}$ である。一方， スタッド高 $80 \mathrm{~mm}$ における相対ずれの最大值は, T20, T30 においてそれぞれ 8.71，6.48mm, スタッド高 $100 \mathrm{~mm}$ ではそれぞれ $11.81,4.38 \mathrm{~mm}$, スタッド高 $120 \mathrm{~mm}$ ではそ れぞれ 15.31，7.47mm である。すなわち本実験では，側 圧比が大きくなるにつれてせん断応力の最大值および相 


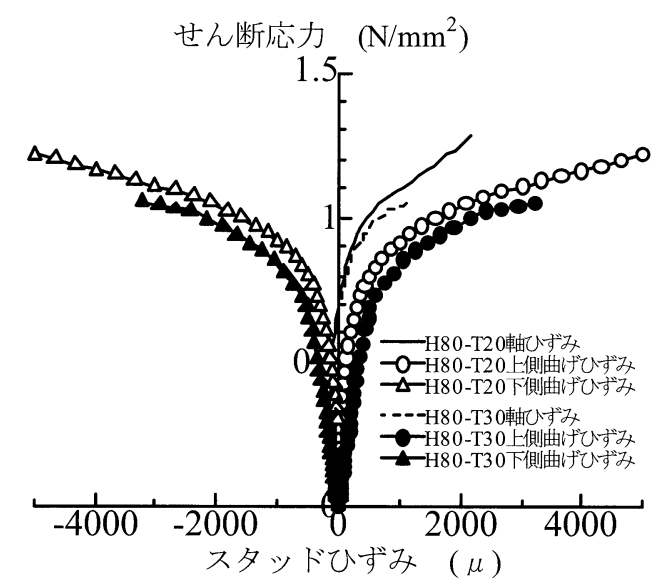

（a） スタッド高 $\mathrm{H}=80 \mathrm{~mm}$

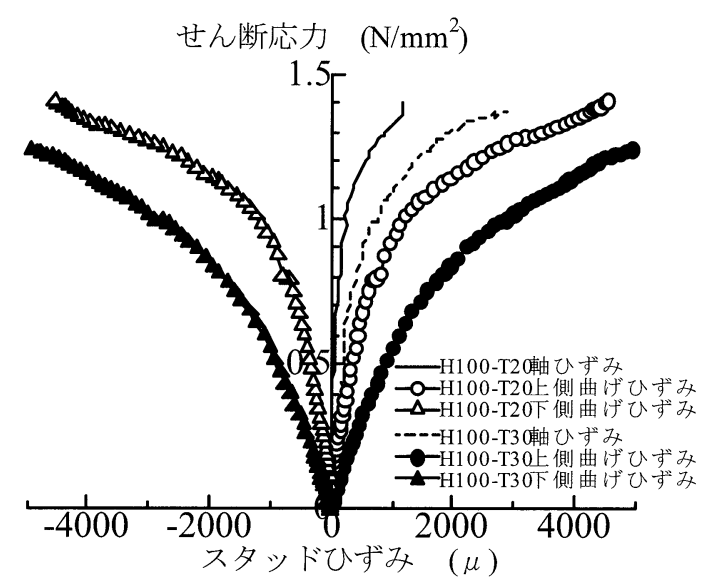

(b) スタッド高 $H=100 \mathrm{~mm}$

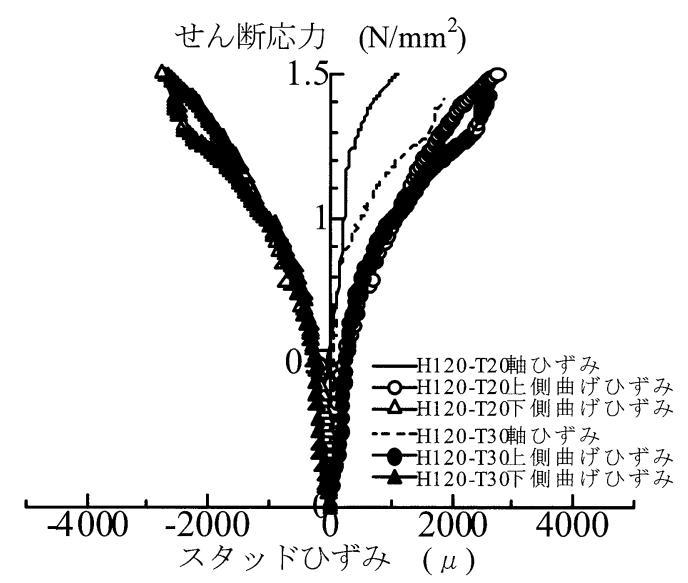

（c） スタッド高 $\mathrm{H}=120 \mathrm{~mm}$

図ー10 せん断応カースタッドひずみの関係 （スタッド高一定）

対ずれの最大值が小さくなるというように，引張力とし ての側圧比の大きさがコンクリートと $\mathrm{H}$ 型鋼の界面の付 着性状に非常に大きな影響を及ぼしているわけである。 さらに，せん断応力および相対ずれの最大值に及ぼす側 圧比の大きさの影響は, スタッド高が高いほど顕著であ る。このような, 側圧比の大きさによる付着性状は, 引 張力としての側圧を作用させることにより，コンクリー
トと $\mathrm{H}$ 型鋼との間にわずかな開きを生じるとともに破壊 面となるコーンが形成され, せん断力の載荷とともに次 節で示すスタッドの曲げ変形が卓越することによるもの である。したがって，側圧が大きいほど上述の開き或い は破壊面となるコーンの形成度合いが大きいため, 側圧 の影響が非常に顕著となるわけである。

一方, 側圧無しの供試体のせん断応力は緩やかに増加 し最大に達した後, 最大值としてのせん断応力を保持し ながら相対ずれが増加する傾向を示している。このよう な性状は，せ九断荷重による曲げが鋼コンクリート界面 の開きとともにスタッドの引き抜きを生じさせることに よると思われる。すなわち, スタッドの伸び挙動により 相対ずれが延性的に増加したものと思われる。

なお，図一8（c）において供試体 H120-T20 の初期剛 性が他の供試体と若干異なるが, これは恐らく $\mathrm{H}$ 型鋼に 溶接する際のスタッドの溶接ひずみがスタッドの剛性に 影響を及ぼしたものではないかと考えられる。

上述のことは鋼コンクリート界面においてスタッド 本数が 1 本に関するものであり, スタッド間隔またスタ ッド本数による側圧比およびスタッド高の性状は今後の 課題としたい。

\section{3 せん断応カ〜スタッドひずみの関係}

スタッドの変形性状は, 軸方向ひずみ成分と曲げひず み成分に分解して考慮することができる。軸方向ひずみ 成分はスタッド中央の上部および下部に添付したスタッ ドひずみの平均により表すことができ，また曲げひずみ 成分については，スタッド上部および下部のスタッドひ ずみの值から軸方向ひずみ成分を差し引くことにより表 すことができる。

本研究では, スタッド中央に貼付したひずみゲージに よりスタッドの挙動を評価したわけであるが，スタッド の局所的挙動に関しては勿論言及はできない。しかしな がら, 本研究の範囲内において供試体の破壊性状がコン クリート破壊であることから, 破壊に至るまでのせん断 忘力はコンクリート内部に存在するスタッドの挙動に密 接に関係しているものと考えられる。さらに，引張力と しての側圧により鋼コンクリート界面にわずかな開きが 生じ, $\mathrm{H}$ 型鋼とコンクリートの付着がスタッドのみであ ると考えられることから，スタッドの変形挙動が及ぼす 鋼コンクリート界面のせん断応力への影響は大きいわけ である。

図ー 10 (a)，(b)および（c）は，それぞれスタッド 高 $80 \mathrm{~mm}, 100 \mathrm{~mm}$ および $120 \mathrm{~mm}$ における側圧比 $20 \%$, $30 \%$ 状態でのせん断応力とスタッドひずみによる比較 を示したものである。図中の実線および記号○、、はそ れぞれ側圧比 $20 \%$ のスッドの軸ひずみ，上側曲げひず みおよび下側曲げひずみを表しており破線および記号・ 、はそれぞれ側圧比 30\%時のスタッドの軸ひずみ，上側 曲げひずみおよび下側曲げひずみを示している。 


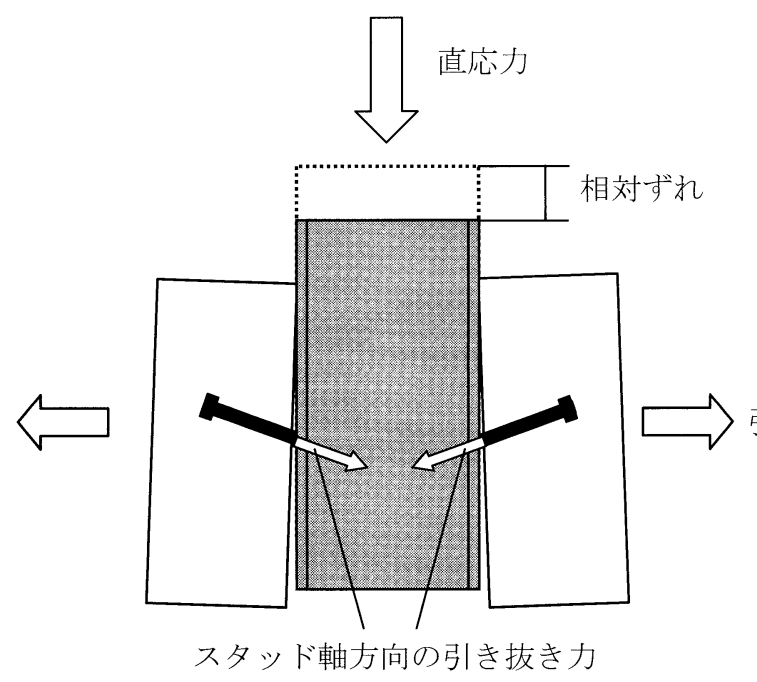

図ー 11 載荷によるスタッドの変形挙動と 引き抜きカ

(1) スタッド高に関する影響

図ー10（a）に示すスタッド高 $80 \mathrm{~mm}$ の軸方向ひず み成分は, せん断力の載荷開始初期には軸方向ひずみ成 分が殆どゼロであり，その後急激に引張の軸方向ひずみ 成分を示した。一方，同図 (b) および (c) に示すスタッド 高 100 および $120 \mathrm{~mm}$ の軸方向ひずみ成分は, せん断力 の載荷直後から引張の軸方向ひずみ成分を示した。また， 曲げひずみ成分において，いずれのスタッド高に関して も，せん断応力が約 $1.00 \mathrm{~N} / \mathrm{mm}^{2}$ に達する辺りにおいてス タッド高が低いほど曲げひずみ成分の増加割合が顕著と なった。また，曲げひずみに関して図ー8に示す相対ず れに関連付けて考察すると, 図一8に示す相対ずれが急 激に増加した時点すなわちせん断応力が約 $1.00 \mathrm{~N} / \mathrm{mm}^{2}$ 近 傍において，図ー 10 に示すスタッドの曲げひずみ成分 が増加している。このことは，スタッド頭部がコンクリ 一ト中に固定されていることからせん断変形に伴う軸方 向ひずみはスタッド基部近傍が最も大きく, その部分で スタッドが降伏したことによるものであると考えられる。 すなわち, スタッド高が低いほど曲げ変形性状が卓越し， 各スタッド高の変形挙動がせん断応力に寄与寸る割合が 異なるわけである。

(2) 側圧比に関する影響

図－10（a）に示すスタッド高 $80 \mathrm{~mm}$ では，軸方向 ひずみ成分に及ぼす側圧比の影響はほとんどないことに 対して, 同図 (b)，(c)に示すスタッド高 100 および $120 \mathrm{~mm}$ では，側圧比が大きくなるにつれて引張の軸方向ひずみ 成分の差異が大きくなる。一方, 曲げひずみ性状は, 側 圧比によって殆ど変化がない。このような性状を図ー8 に示すせん断応力ー相対ずれ関係に関連付けてみると， 引張の軸方向ひずみが大きいほどせん断応力の最大值が 小さくなっていることが確認される。すなわち，側圧比 が大きい程，スタッドの軸方向ひずみが引張として大き

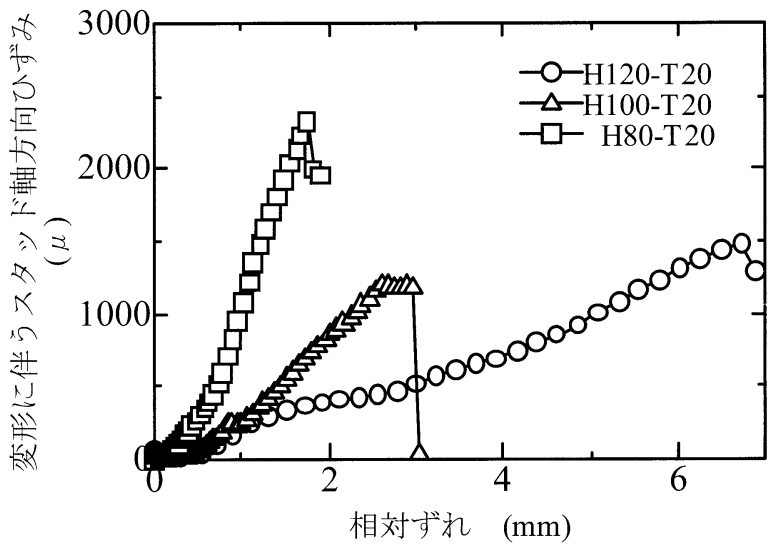

(a) 側圧比 $20 \%$

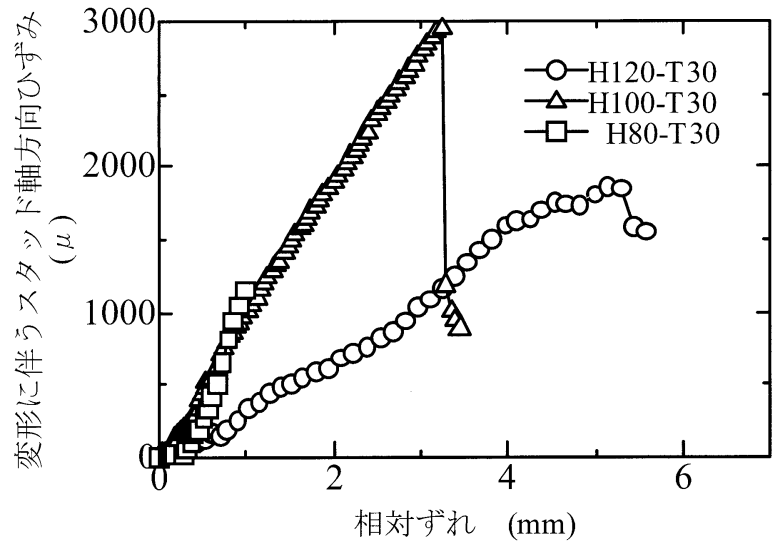

(b) 側圧比 $30 \%$

図-12 軸方向ひずみ一相対ずれの関係

（側圧比一定）

くなり，初期值としての引張力によるコンクリートのひ び割れが，小さなせん断応力でコンクリートのコーン型 破壊領域形成，およびその進行を顕著にさせると考えら れる。

\section{4 スタッドの変形に伴う軸方向ひずみ一相対ずれ の関係}

側圧として引張力を載荷させた場合，引張の影響によ り鋼コンクリート界面にはわずかな開きが発生し，鋼コ ンクリートの付着はスタッドとコンクリートのみである と考えられる。このことから鑑みると，せん断耐力は作 用側圧とスタッドの変形挙動に依存するものであるため, 相対ずれの増加に伴うスタッド変形によるスタッド軸方 向ひず夕を評価する必要があると思われる。図ー 11 に 示す鋼コンクリートの変形挙動を考えてみると, $\mathrm{H}$ 型鋼 の押し抜きにより $\mathrm{H}$ 型鋼とコンクリートには相対ずれが 発生する。その際，スタッド頭部では幾何学的形状によ りコンクリートの拘束が存在するため鉛直方向の移動は 起こらず，同図に示すように，スタッドの挙動は軸方向 の伸びと純曲げ挙動であり，このような開きおよび伸び に関する性状は作用側圧が大きいほど顕著である。また， スタッド軸方向の伸び挙動によるコンクリートからの抜 け出しは，水平方向においては供試体の鋼コンクリート 界面での開きとなり, 鉛直方向においては H 型鋼とコン 
クリートの相対ずれを伴うものであることから，スタッ ドの軸方向の変形性状は鋼コンクリート界面の鉛直方向 および水平方向の変形挙動をよく示すものであると考え られる。

図ー 12 は，側圧比が $20 \%$ よび $30 \%$ におけるタッ ド高をパラメータとしたスタッドの軸方向ひずみと相対 ずれの関係を表している。同図（a）および（b）はそれ ぞれ側圧比 $20 \%$ および $30 \%$ に対するものであり，図中の

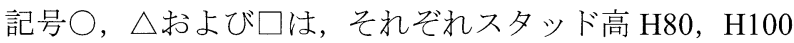
およびH120を表している。

同図（a）に示す側圧比が $20 \%$ の場合，スタッド高が 低いほど相対ずれの増加に伴うスタッド軸方向ひずみの 増加率すなわち傾きが大きくなり，その傾きは相対ずれ によらずほぼ一定であるということが確認できる。これ は，スタッド頭部がコンクリートで固定された状態での 強制変位であることからスタッド高が低いほど偏心曲げ 性状が大きくなり，それによって伸び挙動が顕著になる わけである。また同図（b）に関しても同様である。

同図（a）と（b）の比較による側圧比の差異に関して は，側圧比が大きくなるほど相対ずれに対するスタッド 軸方向ひずみの増加率, すなわち傾きが大きくなる傾向 が確認できる。引張力としての側圧により鋼とコンクリ 一トの付着がスタッドのみに依存していることから， $\mathrm{T} 20$ および $\mathrm{T} 30$ のスタッドには側圧としての引張力とし てそれぞれ約 $150 \mathrm{~N} / \mathrm{mm}^{2}$ および $200 \mathrm{~N} / \mathrm{mm}^{2}$ の引張応力が 作用していることになる。これらの初期応力性状に関し て, T20 はスタッドの弾性域, T30 ではスタッドの塑性 域近傍にまで達しており，初期值としての側圧比の大き さがせん断荷重載荷後のスタッド軸方向ひずみの増加傾 向に影響を与えているものと考えられる。なお，T30の スタッドは塑性域近傍に達しているもののまだ降伏して いないことからせん断力を分担することができ，その後 はスタッドの硬化域およびスタッド抜け出し部分のダボ 効果による変形の拘束により, スタッド基部における破 断をしなかったものと思われる。また，せん断応力一相 対ずれ関係に関連付けてみると，スタッド高が低くなる ほど相対ずれに対するスタッド軸方向のひずみ増加が顕 著となり，最大せん断応力に達するまでの相対ずれ量が 減少すると思われる。なお， H80-T30 は，載荷途中にス タッドに貼付したひずみゲージが剥離したためである。

本研究を基に実構造物におけるスタッドの変形性状に ついて考えてみる。上述の鋼コンクリート界面における スタッド変形挙動に関して, 合成梁のコンクリート床版 において, スパン長方向に連続して存在するずれ止めと してのスタッドには，常時荷重が作用することによる横 方向の曲げによってスタッド軸方向への応力およびせん 断応力が同時に増加しながら作用し，鋼コンクリート界 面で開きおよびスタッド軸方向への伸び挙動を生じる。 柱梁接合部においても，スタッドへの同様の作用応力性
状から開きおよび伸び挙動を示すと思われる。本研究に おいてスタッド本数は 1 本であるが，ずれ止めとして複 数配置されているスタッドのうち，局所的なスタッドに ついては本研究におけるスタッドの変形挙動と程度は異 なるが似たような挙動を示すものと思われる。さらに， 例えば正立した状態で用いられるずれ止めとしてのスタ ッドは，水平方向にはずれを発生させる力に対し，鉛直 方向には版を浮き上がらせる力に対して抵抗するもので あると考えられる。したがって，スタッド軸方向に変形 を生じさせる力は，鋼コンクリート界面の鉛直方向およ び水平方向の変形を促す力の合力としての性状を持つと 考えられるわけである。

以上の節で述べてきたことから，スタッド高および側 圧比の相違は複合応力状態下の鋼とコンクリートの界面 における付着性状に多大な影響を及ぼしているのは明ら かである。すなわち，スタッド高および側圧比をパラメ 一タとし詳細に評価した統一モデルの構築が必要となる わけである。

\section{5 鋼コンクリート界面の付着性状に関する側圧お よびスタッド高依存モデルの構築}

本研究の範囲内における, スタッドを有する鋼コンク リート界面におけるスタッド高を考慮した付着性状の側 圧依存型モデルの構築を行う。引張力としての側圧を載 荷した実験においてコンクリート供試体が脆性的破壊を 示した。この破壊点における最大せん断応力および最大 相対ずれを考慮した引張力としての側圧載荷に及ぼすパ ラメータ推定式およびスタッド変形に伴うスタッド軸方 向応力一相対ずれ関係の推定式をそれぞれ次のように導 出した。

（1）引張の側圧載荷時のせん断応力一相対ずれ関係 の推定

スタッド高をパラメータとした各々の供試体における せん断応力ー相対ずれ関係を回帰分析した結果は以下に 示寸通りである。

$$
\begin{aligned}
& \tau=a+b \ln (s) \\
& a=1.8366-0.006942 H \\
& b=0.3313-0.000292 H \\
& \text { で, } \\
& \tau: \text { せん断応力 }\left(\mathrm{N} / \mathrm{mm}^{2}\right) \\
& s: \text { 相対ずれ }(\mathrm{mm}) \\
& H: \text { スタッド高 }(\mathrm{mm})
\end{aligned}
$$$$
\text { ここで, }
$$

とする。

また，スタッド高の差異によるコーンの抜け出しを考 慮した最大相対ずれ $S_{\text {max }}$ の推定式は次式のようになる。

$$
S_{\text {max }}=\left(1.444 \times 10^{-5}-4.546 \times 10^{-7} L P\right) H^{3}+6.143
$$

ここで,

$S_{\text {max }}:$ 最大相対ずれ $(\mathrm{mm})$

$L P:$ 側圧比 $(\%)$

とする。 


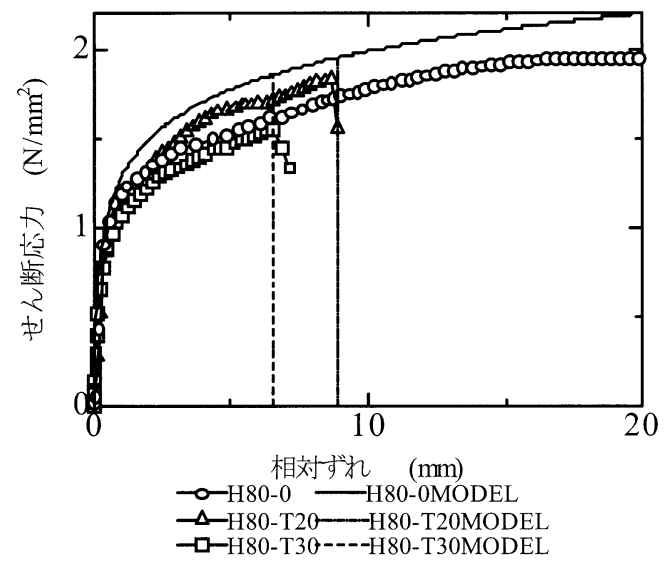

(a) スタッド高 $\mathrm{H}=80 \mathrm{~mm}$

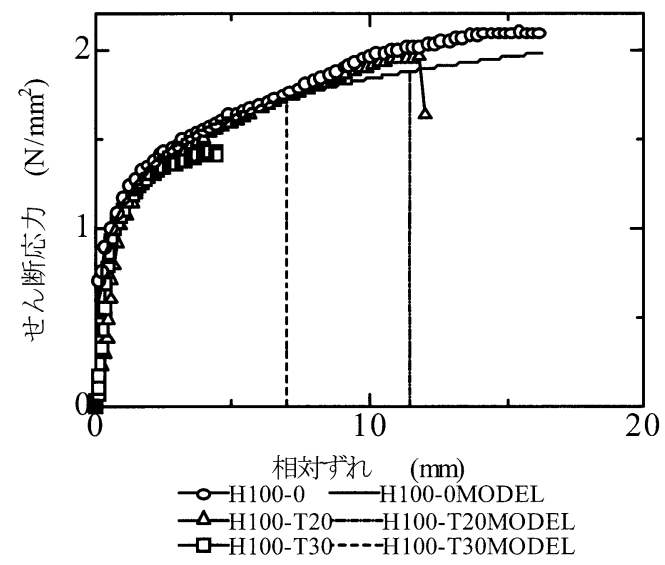

(b) スタッド高 $H=100 \mathrm{~mm}$

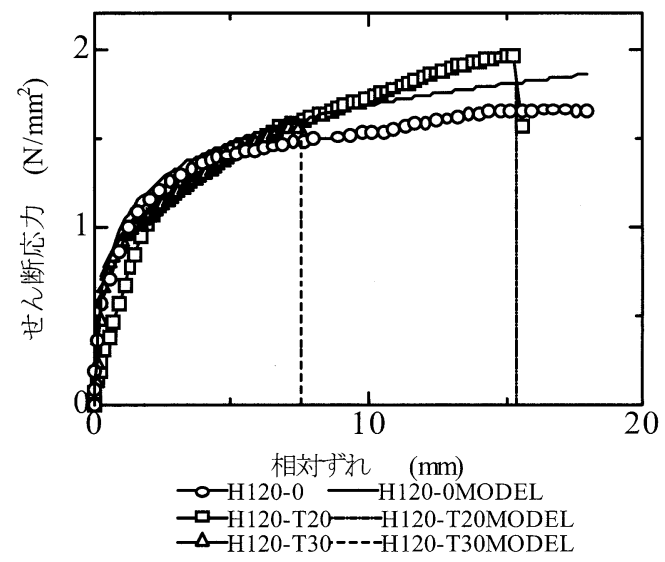

(c) スタッド高 $H=120 \mathrm{~mm}$

図一 13 せん断応カー相対ずれの関係

（スタッド高依存型モデル）

また，比較のため笠井等 ${ }^{1)}$ の行った拘束圧として圧縮 力を与えた状態でのせん断応力一相対ずれの推定式を次 に示す。

$$
\begin{aligned}
& a=0.00519+0.0038 L P \\
& b=\left(0.0062-9.0 \times 10^{-6} H\right) f_{c}^{\prime} \\
& こ こ て ゙, \\
& f_{c}^{\prime}: \text { コンクリート圧縮強度 }\left(\mathrm{N} / \mathrm{mm}^{2}\right)
\end{aligned}
$$
とする。

これより，拘束圧として圧縮力を与えた状態での推定 式ではスタッド高の影響が無視できるほど小さいことが

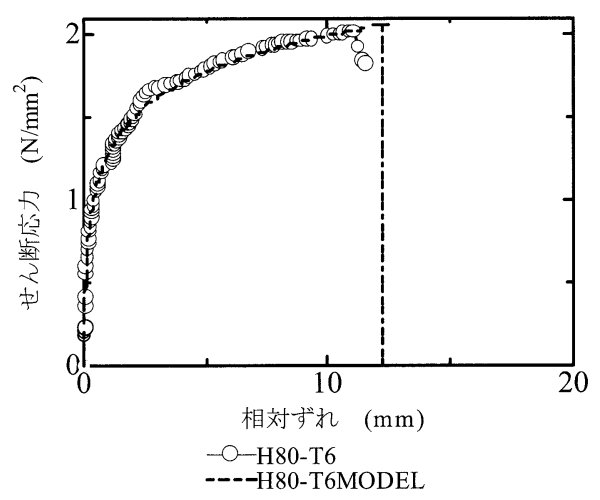

図ー14 低側圧比におけるモデルの適用性

(せん断応カー相対ずれ)

確認できる。また一方では，側圧として引張力を与えた 状態での推定式においては, スタッド高の差異が鋼コン クリートの付着性状に関して非常に大きな影響を及ぼす ということと共に, 最大相対ずれに関しては側圧比の差 異が影響することが確認できる。

そして, 式（3）および式（4）の構築モデルを図－8 に適用した結果を図ー13に示寸。同図（a)，(b) およ び（c）は，それぞれスタッド高 80,100 および $120 \mathrm{~mm}$ に対する結果であり，図中に示す実線，破線および点線 は，それぞれ側圧無し，側圧比 $20 \%$ よび $30 \%$ の引張力 としての側圧における構築モデルの結果を示している。

構築したモデルと本研究での実験結果との比較を行う と，相対ずれにおいては，構築したモデルは鋼コンクリ 一ト界面における付着に急激な減少が発生する時点, す なわち最大相対ずれ量を比較的精度良く評価している。 また，スタッド高 $100 ， 120 \mathrm{~mm}$ においてせん断応力増加 傾向を良く評価し，スタッド高 $80 \mathrm{~mm}$ においては多少ず れがあるものの実験結果を評価しているものと思われる。

次に, 本構築モデルの低側圧比への適用性評価を行う こととする。図ー 14 は, 本構築モデルをスタッド高 $80 \mathrm{~mm}$, 側圧比 6\%の実験供試体 H80-T6 に対して適用し たものである。H80-T6 は本研究の実験パラメータとして 表ー3に示しておらず実験結果に関する議論も行ってい ないが，低側圧比における本構築モデルの適用性評価の ため同図に示したものである。構築したモデルと供試体 H80-T6 との比較を行うと, せん断応力の増加経路を非常 に精度よく評価しており, 最大相対ずれの值に多少のず れがあるものの本構築モデルは低側圧比にも適用可能で あると考えられる。

なお，4. 2 にて述べたとおり供試体 H100-T30 は，他の 実験供試体とは異なる破壊形態のスタッド基部での溶接 部破断であったため他との比較が困難である。また，側 圧無しに関しては, 本研究の範囲内では明瞭な破壊点を 示していないため, 最大相対ずれの算出は困難であった。

（2）引張の側圧載荷時の軸方向応力ー相対ずれ関係 の推定

側圧としての引張力を初期応力として考慮した変形に 


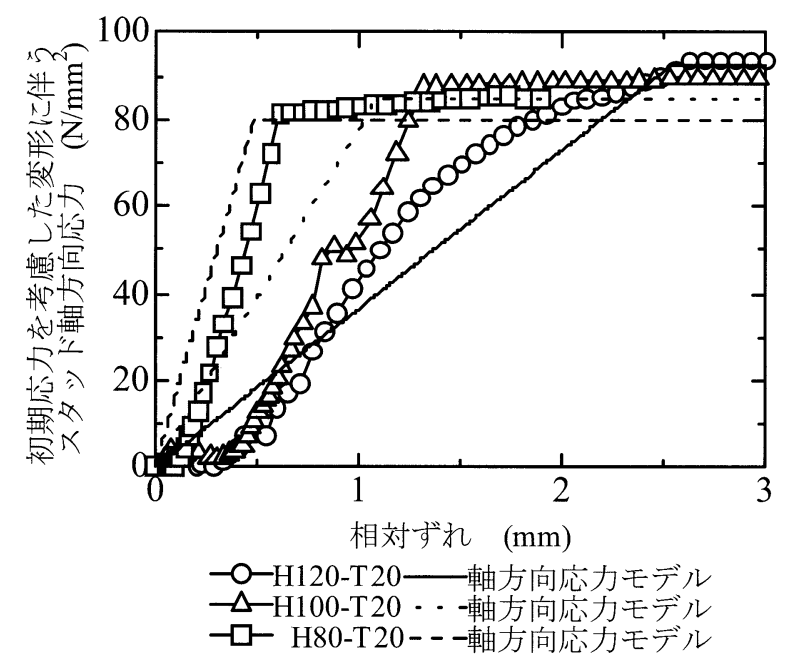

(a) 側圧比 $=20 \%$

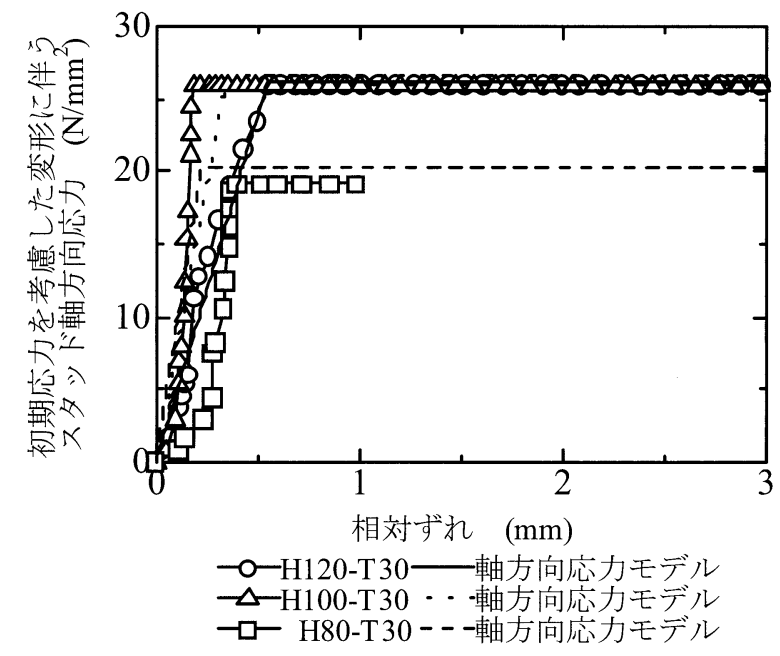

(b) 側圧比 $=30 \%$

\section{図-15 軸方向応カー相対ずれの関係 \\ （側圧およびスタッド高依存型モデル）}

伴うスタッド軸方向応力ー相対ずれ関係を回帰した結果 を図ー 15 に示す。同図（a）および（b）はそれぞれ側 圧比 $20 \%$ おび $30 \%$ に対する結果であり, 図中に示す実 線, 点線および破線は, それぞれスタッド高 $80 \mathrm{~mm}$, $100 \mathrm{~mm}$ および $120 \mathrm{~mm}$ における回帰の結果を示している。

変形に伴うスタッド軸方向応力ー相対ずれ関係の推定 式は以下の通りである。

$$
\begin{aligned}
\sigma_{a s} & =E(\alpha+\beta S)+\sigma_{0} \quad\left(\sigma_{\mathrm{y}} \leq \sigma_{0}\right) \\
\alpha & =-0.00034+0.7324 \times 10^{-6} L P+2.0576 \times 10^{-6} H \\
\beta & =0.002606+8.3862 \times 10^{-6} L P-20.8429 \times 10^{-6} H \\
\sigma_{a s} & =\sigma_{\mathrm{y}} \quad\left(\sigma>\sigma_{\mathrm{y}}\right)
\end{aligned}
$$

ここで,

$$
\begin{aligned}
& \sigma_{a s} \text { : スタッド軸方向応力 }\left(\mathrm{N} / \mathrm{mm}^{2}\right) \\
& E: \text { スタッドの弾性係数 }\left(\mathrm{kN} / \mathrm{mm}^{2}\right) \\
& S: \text { 相対ずれ }(\mathrm{mm}) \\
& \sigma_{0} \text { : 側圧によるスタッドの初期応力 }\left(\mathrm{N} / \mathrm{mm}^{2}\right) \\
& \sigma_{\mathrm{y}}: \text { スタッドの降伏応力 }\left(\mathrm{N} / \mathrm{mm}^{2}\right)
\end{aligned}
$$

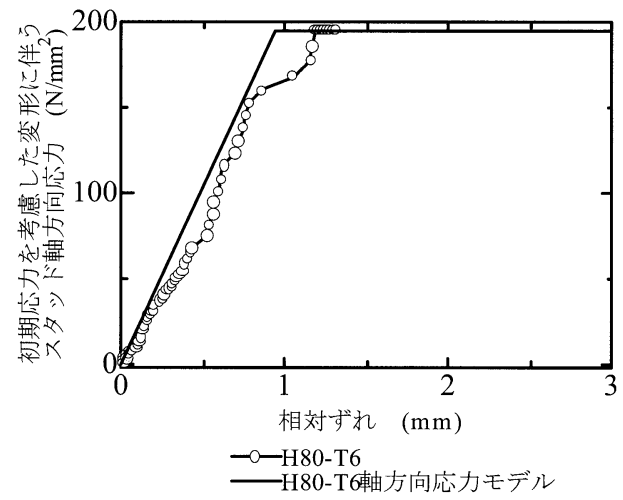

図ー16 低側圧比におけるモデルの適用性

（スタッド軸方向応カー相対ずれ）

$$
\begin{aligned}
& L P: \text { 側圧比 }(\%) \\
& H: \text { スタッド高 }(\mathrm{mm})
\end{aligned}
$$

とする。

また, 図ー16に構築モデルの低側圧比への適用性の 検討として, 側圧比 6\%における実験供試体 H80-T6 の実 験に対して，構築モデル式（5）および式（6）を適用し た結果を示す。構築したモデルと供試体 H80-T6 との比 較を行うと, 本構築モデルは, 相対ずれの増加に伴うス タッド軸方向ひずみの増加率である傾きを精度良く評価 しており，低側圧比にも適用可能であると考えられる。

せん断耐力およびスタッド軸方向応力はパラメータと しての側圧比, スタッド高およびスタッドの降伏に関係 しており今回算出したような推定式のように式(3)，(4)， （5）および（6）のそれぞれを独立ではなく従属に評価, 考察することが重要であると思われる。また, さらに広 範囲におけるスタッド高への適用性に関して, 構築した 側圧およびスタッド高依存型モデルはスタッド 1 本に対 して構築されたものであるため, スタッドの本数, スタ ッドの径或いはコンクリート強度等への本モデルの拡張 および解析的検討と本モデルとの適用性評価は今後の課 題としたい。

\section{5. 結論}

本研究では, 鋼コンクリートの付着性状に焦点を当て, パラメータとして側圧およびスタッド高が鋼コンクリー トに及ぼす影響を評価するため, 引張力を載荷した状態 での改良型押し抜き試験を実施, 考察し, 実験データを 用いた鋼コンクリート界面における耐荷力モデル式の提 案を行った。

本実験で得られた結果は，以下のとおりである。

（1）スタッド高を高くすることは，コンクリートとスタ ッドの付着面積増加に伴い, 最大相対ずれが大きくな り，最大せん断応力がわずかであるが大きくなる傾向 にあった。

（2）側圧比が大きくなることは，スタッドの軸方向ひず 
み成分が増加し鋼コンクリート界面の開さおよび破壊 面の形成を促進し, 最大せん断応力および最大相対ず れが小さくなる。

(3) 実験パラメータとして側圧比およびスタッド高を変 化させてもせん断応力の増加経路には変化はみられず 同じような経路で上昇する。

(4) 本研究におけるせん断応力一相対ずれ関係に関する 構築モデルは, スタッド高 100 および $120 \mathrm{~mm}$ におい て比較的良い精度を示した。

（5）複合応力状態下におけるスタッドのせん断耐力は, 作用側圧により変化しコンクリート破壊, スタッド破 断を同様に評価するのは困難であると思われる。

（6）初期值としての側圧比の大きさがせん断荷重載荷後 のスタッド変形性状に大きな影響を及ぼす。
参 考 文 献

1)笠井祐次, 河村哲男, 大下英吉：スタッド付き鋼・コンクリート界面 の付着性状に及ぼす側圧効果の影響に関する研究, コンクリート工学 論文集，Vol.13,No.2,pp.1-13,2002.

2)阪神・淡路大震災調査報告編集委員会 : 阪神・淡路大震災調査報告 建 築編-2, 日本建築学会他, 1998

3) 土木学会構造工学委員会鋼・コンクリート合成構造小委員会 : 鋼・コ ンクリート合成構造の設計ガイドライン, 土木学会, 1989

4) 黒木勇人, 太田貞次, 香月智, 石川信隆 : C F T 柱・合成コンクリー 卜梁接合部の高速破壊実験, 構造工学論文集, Vol.45A, pp.1439-1450,1999,3

5)大谷恭弘, 馬場真吾, 森戸義貴, 福本唀士 : 組合せ荷重を受けるスタ ッド・アンカーの挙動, 構造工学論文集, Vol.37A,pp.1387-1396,1991,3. 6)笠井裕次, 山野誠悦, 河村哲男, 大下英吉：スタッドを有する鋼コン クリート界面に㧍ける付着性状の統一的モデルに関する研究, コンク リート工学年次論文報告集, Vol.22,No.3,pp.1171-1176,2000.

7)成瀬勝武, 鈴木俊男 : 橋梁工学 (鋼橋編), 森北出版, pp.245-253,1999. (原稿受理年月日：2002 年 9 月 6 日)

\section{Experimental Study on Bond Characteristic Depending on Lateral Tensile Stress between Steel Plate with Stud and Concrete}

\section{By Masashi Toyama and Hideki Oshita}

Concrete Research and Technology, Vol.15, No.1, Jan. 2004

Synopsis: In this study, a qualitative and quantitative estimation of bond characteristic under comprehensive stress state due to applying the lateral pressure with tensile stress in the direction of a stud axis, was carried out. As a result, it is noted that a bond characteristic was greatly influenced of a lateral pressure with tensile stress and then a bond characteristic depending on lateral pressure was constructed.

Keywords: composition structure, stud, bond characteristic, depending on tensile stress 